\title{
Startup Performance: The Interplay of Market Orientation and Network
}

\author{
Euna Lee \\ Graduate Student, School of Business Administration \\ Kyungpook National University \\ Republic of Korea \\ Yunsoo Shim \\ Graduate Student, School of Business Administration \\ Kyungpook National University \\ Republic of Korea \\ Jounghae Seo \\ Professor, School of Business Administration \\ Kyungpook National University \\ Republic of Korea
}

\begin{abstract}
This research identified the potential of improving market opportunities inherent in the network, to study the impact of market orientation on the performance of startup companies. The research was conducted to clarify the relationship between market orientation, firm performance, and networks. It also attempted to identify the role of each aspect. An empirical study was performed on 135 startup companies. PLS-based SEM was used to evaluate the fit of the research model. First, the results of the study confirmed that the market orientation of startup companies had a positive impact on firm performance. Both the Narver \& Slater (1990) scale and Kohli \& Jaworski (1990) scale, which is used as a representative measure of market orientation, appeared to be positively related to firm performance, making it suitable for measuring the performance of startup companies. Second, it was shown that the network had a negative moderating effect on market orientation and firm performance of startup companies. The research found that as the market orientation increased, the firm performance also increased. But when the network grew stronger, the firm performance became weak. The effect of a negative moderating effect was only shown in the Narver \& Slater (1990) scale. This study could provide some implications for future market orientation-related studies on startups, and for entrepreneurs who actually wish to start a new business.
\end{abstract}

Keywords: market orientation, network, startup performance, PLS-SEM

\section{Introduction}

Due to the overheated competition and technological complexity in the global market, the importance of an innovated business model that combines various competencies and new technologies is increasing in order to secure a competitive edge. As a result, 'startup companies' are drawing more interest as an alternative that can meet the changing environmental needs and trends. Recently, with the rapid growth of the startup ecosystem in Korea, many types of research are being conducted to identify not only the importance and economic effects of startups in a macro level but also the factors that influence the organizational performance of startups in a micro level.

In the process of creating new products and developing new markets to secure/maintain a sustainable competitive edge, the importance of 'market orientation' is drawing a lot of attention from many, since it can provide new ways to discover new changes in the market while also helping the startups to provide new values to their customers through their products and services. For startups to gain a competitive edge in the market, they should consider strengthening its competitiveness through many ways such as understanding customer needs, actively responding to their competitors, developing/applying new technology, and establishing a better way of communication, etc.

In addition, the entrepreneur's network is an important method of acquiring new knowledge and resources (McEvily \& Zaheer, 1999), and exchanges through these networks allow them to acknowledge new opportunities and help them develop (Singh et al., 1999). Startups can overcome their lack of resources by utilizing these networks to share new technologies/knowledge and increase market opportunity (Gulati \& Singh, 1998). Naturally, the utilization of networks is even more crucial for these startups since it can help them maximize their performance from market orientation. 
Despite these facts, however, only a few empirical studies that focus on market orientation and the Korean startup network have been conducted. Thus, this study first focused on observing the direct effects of market orientation on startup performance. Furthermore, it had attempted to confirm the interaction of networks that can maximize the effect of market orientation. In particular, the study had successfully secured a reliable sample by collecting data from startups that have been in business for less than 7 years. Thus, this study is differentiated from existing research because it conducted an empirical study on a subject that hadn't been sufficiently addressed before, and it also analyzed the effect of the network in a more comprehensive way.

In this research, SmartPLS 3.0 was used to evaluate the fit of the research model by confirming the reliability and validity. Then, the significance of the hypothesis was verified through path analysis. The results of this study are expected to provide new suggestions for improving the performance of market orientation in Korean startups, and expanding the growth base for startup companies.

\section{Conceptual framework}

\subsection{Market Orientation}

Market orientation can be understood as an organizational tendency to consider their competitors when deciding which actions they would make while putting the satisfaction of the customers as a top priority. Its purpose is to implement marketing activities in the market. Market orientation refers to the skills and abilities of companies to understand and satisfy customers, put customer benefits as a top priority, create valuable information about their competitors and customers, spread such information or transfer such information into a more useful form, and coordinate resources to create the best value for their customers (Day, 1994). Market orientation has been an important issue in the field of marketing/group organization for the last 20 years, and there have been ongoing studies on operationalizing the concept itself or linking the concept with other factors such as organizational performance, strategic orientation, innovation, and sales management.

Although the concept of market orientation was discussed by many, the concept mostly developed around two different perspectives: Organizational culture-based perspective represented by Narver \& Slater (1990), and an organizational behavior-based perspective represented by Kohli \& Jaworski (1990).

Narver \& Slater (1990) recognized market orientation in a cultural point of views, and defined market orientation as a corporate culture that focuses on effectively and efficiently creating necessary actions to create superior value for the buyers, thereby constantly providing the company with superior performance. Market orientation was defined as a culture that places priority on the creation and maintenance of excellent customer value while providing a certain set of norms to appropriately respond to the market and systematically develop market information (Slater \& Narver, 1995). Moreover, Slater \& Narver added that market orientation allows the company to collect information about their customers and competitors and spread such information within the organization, and the organization can use this information to create customer value and respond to their competitors through cross-departmental collaboration.

Through this, they have explained that the concept of market orientation consists of three different components: Customer Orientation, Competitor Orientation, and Interfunctional Coordination. Customer orientation refers to the corporate behavior and actions which they focus on providing customer satisfaction by defining desires and needs from the perspective of their customers so that the company can achieve its own goals. Competitive orientation refers to the organizational tendency to prepare for current and potential competitors by identifying SWOT. Interfunctional coordination refers to the activities of a company -based on information collected about customers and competitorswhich they coordinate with each other and adjusts their resources to meet customer needs and create value.

However, Kohli \& Jaworski (1990) approached market orientation as a form of organizational behavior, defining it as a way to execute certain marketing concepts. They defined market orientation as a corporate behavior which the companies create market information regarding current/future customer needs, spread the information to the entire organization, and respond quickly based on such information. Through this, Kohli \& Jaworski divided market orientation into three different elements: Intelligence Generation, Intelligence Dissemination, and Responsiveness. Intelligence generation is an activity where the company collects and generates all kinds of information about the market, including the collection and evaluation of the current/future needs of customers.

Intelligence dissemination refers to the activity where the company spreads such market information within the organization to respond quickly to the changes in the market. Responsiveness refers to a set of activities which the company performs as a reaction to the generated/disseminated market information.

Both scales from Narver \& Slater (1990) and Kohli \& Jaworski (1990) are most commonly used during the utilization of the term 'market orientation' in the academic field and in practice. Both scales are widely recognized for their validity, excellence, and accuracy, and it can be expanded/utilized in various industrial environments. 
Regarding this study, it was decided that using only one of these two scales to measure market orientation would lead the research to overlook an important aspect of the concept of market orientation. So, in order to find out which scale would be appropriate for measuring market orientation for startups, both scales were used to evaluate the scales themselves while identifying the relationship between performances.

\subsection{Market Orientation and Performance}

Market-oriented companies tend to analyze their competitors' capabilities and strategies and, based on the understanding of such information, they try to develop better products/services which their competitors cannot offer (Morgan et al., 2009) Based on this logic, many empirical studies have sought to identify the relationship between market orientation and firm performance. And in most studies, it was shown that market orientation had a positive impact on firm performance (Baker \& Sinkula, 1999; Jaworski \& Kohli, 1993; Li et al., 2008).

Analyses of factors affecting firm performance have shown that market orientation, relative size, relative cost, market growth, and technological change have had a significant impact on ROA (Narver \& Slater, 1990), and it was also shown that market orientation had a positive relationship on the overall firm performance recognized by managers (Jaworski\&Kohli, 1993). In addition, Esteban et al. (2002) had analyzed the positive causal relationship between market orientation and customer satisfaction in service companies, suggesting that market orientation can be an important factor in not only the internal organization of companies but also in market growth.

As seen in previous studies, market orientation was an important factor to improve the overall performance of a company. The following hypotheses were created based on the fact that discovering new market information and spreading/sharing it can have a positive effect on the firm performance of startups.

Hypothesis 1: There is a positive relationship between market orientation (NS) and performance of startups.

Hypothesis 2: There is a positive relationship between market orientation (KJ) and performance of startups.

\subsection{Moderating Effect of Network}

Networks are not a static element. Instead, it is a dynamic, complex, and evolving organism. The structural characteristics of the network can be seen as the dynamics of the network (Mongeet al., 2003). A manager with a wide range of networks can quickly identify new opportunities while developing marketable products and services even during the time of technological turbulence (Burt, 2000). Networks are considered as an important asset to the companies since it can allow them to find new opportunities and secure valuable resources at prices that are lower than the market price (Stam et al., 2014). Networks seem to have a more significant impact on early-stage businesses, which is because entrepreneurs who own various networks and structural holes that allow them to connect with different groups can obtain quality information from other groups (Stam et al., 2014).

Boso et al. (2013) suggested that the founder's social network and the business network can positively moderate the effect of strategic orientation on firm performance. This means that in a market with a weak structure, personal human capital can play a significant role. Mu et al. (2017) stated that in order to access external information based on market orientation, it is important to establish a network and efficiently utilize it. The study also added that the manager's personal network could help improve the quality \& performance of a new product by improving relationships with stakeholders within the company, who often control the resource allocation process and decides the strategic direction of the company. This suggests that the decision-making body can manage the diverse relationships within the company, through this, they can maximize the positive functions of strategic orientation by successfully mobilizing support from stakeholders.

As seen in previous studies, the network is an important factor to improve the performance of market orientation. Based on this fact, the following hypotheses were created.

Hypothesis 3: Network will moderate the relationships between market orientation (NS) and performance of startups.

Hypothesis 4: Network will moderate the relationships between market orientation (KJ) and performance of startups. 


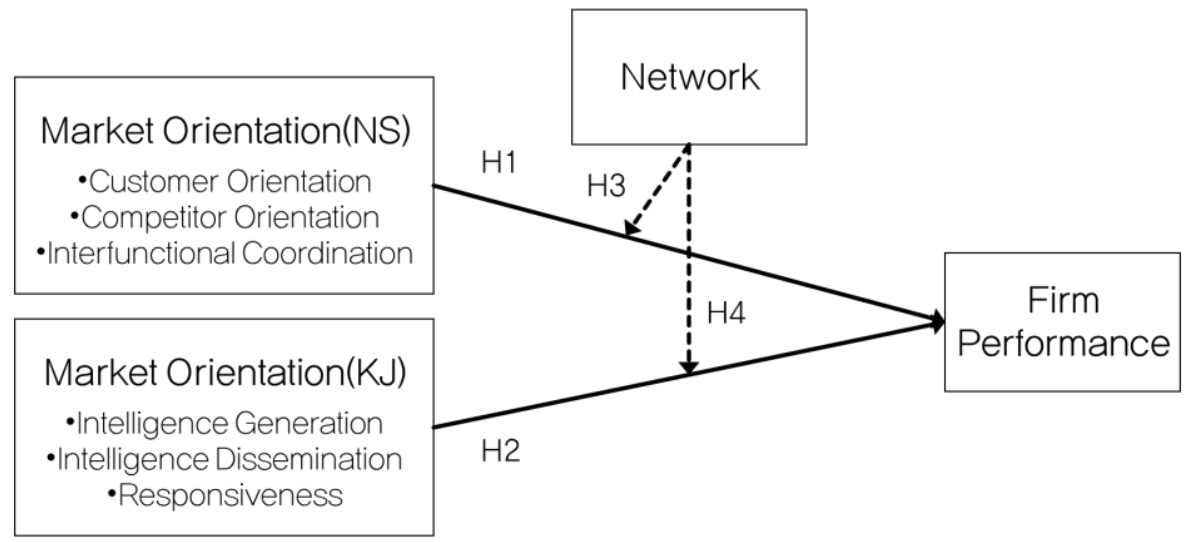

\section{Research Design}

Figure 1: conceptual model

\subsection{Sample}

The survey was conducted for about two months from April 2017. A total of 746 company information was obtained by matching the list of major start-up support organizations in Korea with the data of the start-up portal site. The purpose and contents of the study were explained by e - mail or telephone, and the questionnaire responses were collected directly by visiting them as needed. We excluded firms with more than 7 years of experience and those who were not responding to the survey. The final 135 firms were selected as the empirical analysis sample.

Among the selected startups, $44.4 \%$ of them were established within the last 3 years. Regarding company size, $36.3 \%$ of them had less than 5 employees. Most of them focused on IT-based business areas, and $63.0 \%$ of the companies were in the commercialization stage, which is the stage where the company starts to generate profit by releasing products/services.

Table 1: Characteristics of Sample Startups $(\mathbf{N}=135)$

\begin{tabular}{|l|l|c|c|}
\hline \multicolumn{1}{|c|}{ Construct } & \multicolumn{1}{|c|}{ Classification } & Frequency & \% \\
\hline Firm Age & $1 \sim 2$ & 60 & 44.4 \\
& $3 \sim 4$ & 54 & 40.0 \\
& $5 \sim 6$ & 21 & 15.6 \\
\hline Firm Size & $2 \sim 4$ & 49 & 36.3 \\
& $5 \sim 9$ & 43 & 31.9 \\
& $10 \sim 14$ & 20 & 14.8 \\
& $15 \sim 19$ & 10 & 7.4 \\
& $20 \sim$ & 13 & 9.6 \\
\hline Related Technology & IT (informationtechnology) & 85 & 63.0 \\
& BT (Bio Technology) & 12 & 8.9 \\
& NT (Nano Technology) & 2 & 1.5 \\
& ET (Environmental Technology) & 7 & 5.2 \\
& CT (Culture Technology) & 16 & 11.9 \\
& Other Technologies & 13 & 9.6 \\
\hline Developmental Stages & founding stage & 30 & 22.2 \\
& Commercialization stage & 85 & 63.0 \\
& growth stage & 13 & 9.6 \\
& mature stage & 4 & 3.0 \\
& decline stage & 3 & 2.2 \\
\hline
\end{tabular}

\subsection{Measures}

- Market Orientation

Market Orientation 15-item measure used a 1 (not descriptive) to 5 (very descriptive) Likert-type scale. We use 12 items from Narver \& Slater's (1990) measure of market orientation. Each of a business's customer orientation, competitor orientation, and interfunctional coordination activities is represented by four items in the scale $(\alpha=.817)$. 
We use 15 items from Kohli et al. (1993) measure of market orientation. Each of a business's intelligence generation, intelligence dissemination, and Responsiveness is represented by four-six items in the scale $(\alpha=.880)$.

- Network

All four items used in the empirical analysis were measured using a 5-point Likert scale. The 'network' was measured by referring to the studies of De Clercq et al. (2009) and Tsai \& Ghoshal (1998). It was measured in four categories: Frequency/Strength of network connection in Work/Non-Work related situations $(\alpha=.918)$.

- Firm Performance

All four items used in the empirical analysis were measured using a 5-point Likert scale. To measure the performance of entrepreneurial orientation, many dependent variables such as financial performance, innovation performance, etc. are being used. Many studies measure perceived performance (De Clercq et al., 2011; Stam \& Elfring, 2008; Wiklund \& Shepherd, 2003; Zahra \& Covin, 1995). Based on studies by Zahra (1996), Slater \& Narver (1994), Kohli et al. (1993), the study used four items -market share, sales, ROI, production efficiency for the recent 3 years compared to competitors- to measure firm performance. The firm performance of startups was measured by combining perceived financial/non-financial performance $(\alpha=.916)$.

- Control Variables

The firm size and firm age are used as control variables because they have a significant effect on the performance of the start-up through the corporate resources and organizational structure.

\section{Analysis and Results}

The structural model was tested using SmartPLS 3.0 because SmartPLS works well with small sample sizes, and it is appropriate for both reflective and formative constructs. Moreover, it also works well for the aims of exploratory or theory development research (Hair et al., 2012).

\subsection{Assessing Measurement Model}

Confirmatory factor analysis using SmartPLS 3.0 assesses the measurement model. The factor loadings of the indicators are all above 0.6 and significant, ranging from 0.761 to 0.930 , which reveals the presence of construct validity. Cronbach's alpha, rho_A and composite reliability are acceptable, when compared to the threshold of 0.7, ranging from 0.817 to 0.941 . Convergent validity is acceptable, when compared to the threshold of the average variance extracted (AVE) of 0.5, ranging from 0.731 to 0.806 . Discriminant validity is acceptable based on the rule that the correlation between any two distinct constructs is lower than the square root of the AVE from these constructs (Fornell \& Larcker, 1981).

It is confirmed that both the reliability and the validity of the measurement model are secured by combining the above results. In addition, to evaluate the multicollinearity, the internal VIF value was evaluated as less than 5, and it was confirmed that there was no multi-collinearity among the independent variables for predicting the dependent variable (Hair et al, 2011).

Table 2: Construct reliability and validity

\begin{tabular}{|c|c|c|c|c|c|c|}
\hline \multicolumn{2}{|r|}{ Construct } & $\begin{array}{c}\text { outer } \\
\text { loadings }\end{array}$ & $\begin{array}{l}\text { Cronbach } \\
\text { 's Alpha }\end{array}$ & rho_A & CR & AVE \\
\hline $\begin{array}{l}\text { Market } \\
\text { Orientation(NS) }\end{array}$ & $\begin{array}{l}\text { Competitor Orientation } \\
\text { Customer Orientation } \\
\text { Interfunctional Coordination }\end{array}$ & $\begin{array}{l}0.822 \\
0.883 \\
0.859\end{array}$ & 0.817 & 0.828 & 0.891 & 0.731 \\
\hline $\begin{array}{l}\text { Market } \\
\text { Orientation }(\mathrm{KJ})\end{array}$ & $\begin{array}{l}\text { Intelligence Dissemination } \\
\text { Intelligence Generation } \\
\text { Responsiveness }\end{array}$ & $\begin{array}{l}0.908 \\
0.853 \\
0.930\end{array}$ & 0.880 & 0.898 & 0.926 & 0.806 \\
\hline Network & $\begin{array}{l}\text { S1 } \\
\text { S2 } \\
\text { S3 } \\
\text { S4 }\end{array}$ & $\begin{array}{l}0.837 \\
0.874 \\
0.828 \\
0.761 \\
\end{array}$ & 0.918 & 0.938 & 0.941 & 0.801 \\
\hline $\begin{array}{l}\text { Firm } \\
\text { Performance }\end{array}$ & $\begin{array}{l}\text { p1 } \\
\text { p2 } \\
\text { p3 } \\
\text { p4 }\end{array}$ & $\begin{array}{l}0.897 \\
0.901 \\
0.914 \\
0.864\end{array}$ & 0.916 & 0.921 & 0.941 & 0.799 \\
\hline
\end{tabular}


Table 3: Discriminant validity (Fornell-Larcker Criterion)

\begin{tabular}{|c|c|c|c|c|}
\hline & $\begin{array}{c}\text { Market Orientation } \\
(\mathrm{KJ})\end{array}$ & $\begin{array}{c}\text { Market Orientation } \\
(\mathbf{N S})\end{array}$ & firm performance & Network \\
\hline $\begin{array}{c}\text { Market Orientation } \\
(\mathrm{KJ})\end{array}$ & $\mathbf{0 . 8 9 8}$ & $\mathbf{0 . 8 5 5}$ & & \\
\hline $\begin{array}{c}\text { Market Orientation } \\
\text { (NS) }\end{array}$ & 0.802 & 0.537 & $\mathbf{0 . 8 9 4}$ & \\
\hline $\begin{array}{c}\text { firm performance } \\
\text { Network }\end{array}$ & 0.509 & 0.596 & 0.377 & $\mathbf{0 . 8 9 5}$ \\
\hline
\end{tabular}

\subsection{Assessing Structural Model: Hypotheses testing}

The structure model is analyzed using structural equation modeling (SEM) conducted in SmartPLS 3.0.The bootstrapping procedure was performed to verify the significance of the coefficients. It is possible to evaluate the significance and suitability of the path coefficients by using the iterative regression analysis to reconstruct and extract a large number of bootstrap samples (Tenenhaus et al., 2005). We set up 5,000 samples of Bootstrap Resampling, and the results of testing the statistical significance of hypotheses after calculating the t-value are shown in Table 4.

As a result, both hypothesis 1 (N\&S scale) and hypothesis 2 (K\&J scale) were supported at a significance level of 0.01 . Hypothesis 3 was supported at a significance level of 0.01 , but it had a negative moderation effect. Hypothesis 4 was rejected.

Table 4: Path coefficients and t-values

\begin{tabular}{|c|c|c|c|c|c|}
\hline \multicolumn{2}{|c|}{ Hypotheses } & $\boldsymbol{\beta}$ & T Values & P Values & Result \\
\hline H1 & Market Orientation (NS) -> firm performance & 0.475 & 5.203 & 0.000 & Accept \\
\hline H2 & Market Orientation (KJ) -> firm performance & 0.449 & 4.163 & 0.000 & Accept \\
\hline H3 & Market Orientation (NS) * Network (Moderating Effect) & -0.352 & 3.006 & 0.003 & Accept \\
\hline H4 & Market Orientation (KJ) * Network (Moderating Effect) & -0.244 & 1.907 & 0.057 & - \\
\hline
\end{tabular}

\section{Discussion and Conclusions}

This study was conducted to find a way to improve the performances of startup companies, which is widely considered an important alternative in the current business environment due to its high flexibility and adaptability. In the process of creating new products and developing new markets to secure/maintain a sustainable competitive edge, the importance of 'market orientation,' which is considered as an organizational culture/pattern of behavior, is increasing rapidly, since it can help the startups provide new values to their customers through their products and services. After the establishment phase, which is the time when the performance of the startups become visible, every startup company must consider increasing its competitiveness through various ways such as understanding customer needs, actively responding to competitor information, technology development/application, and better communication. It is also important for startups to recognize and develop more opportunities through network exchange in order to acquire new knowledge and resources. This way, the startups can overcome their lack of resources.

This research focused on the moderating effects of the network to study the impact of market orientation on startup performance. First, it was found that the market orientation of startups had a positive impact on firm performance. Second, it was confirmed that the network has a negative moderating effect on market orientation and performance of startups. It was found that firm performance increases as market orientation increase, but on the other hand, the performance is weakened when the network becomes strong. The negative moderating effect was only significant on the scales of Narver \& Slater (1990). 
The meaning of these results is as follows. The results support the conclusion of a prior study that suggests market orientation has a positive effect on firm performance (Baker \& Sinkula, 1999; Jaworski \& Kohli, 1993; Li et al., 2008), and it also confirmed that market orientation is also an important factor in the performance of Korean startups. Both scales of market orientation -Narver \& Slater (1990), Kohli \& Jaworski (1990)- appear to be positively related to business performance, which means that both scales are suitable for measuring startup performances. This means that startup needs to collect information about their customers and competitors, spread such information within the organization, and perform inter-departmental collaboration to create value while responding to their competitors in order create/maintain a competitive edge and grow continuously. At the same time, it means that they need to generate market information about current/future customer needs, spread it across all departments, and strengthen organizational activities so they can respond quickly to internal/external changes. The result of the empirical study, which showed that the size of direct effects was more significant in the Narver \& Slater (1990) scale -representing corporate culture- than the Kohli \& Jaworski (1990) scale -represents corporate behavior-, shouldn't be taken as absolutes. Instead, it suggests that startups mostly focus on cultivating a healthy corporate culture in their early stages. So, both concepts of market orientation should be applied in future studies.

However, although the negative moderating effect of the network has significantly appeared, it is necessary to find out whether this phenomenon can be identified as a common trait in early-stage startups or is it influenced by other social capitals excluding network. Further research on this subject is necessary since the network can be used as an effective social capital to increase the effect of market orientation. Naturally, in further research, other factors should be considered regarding the context of market orientation.

The limitations of this research are as follows. Due to the lack of prior research on market orientation and networks of startups, it had a weak theoretical foundation. Also, the number of startups that were producing meaningful results were limited, which led to a lack of samples for statistical analysis. In addition, limited consideration of external networks has restricted the research from digging deeper into the subject. Furthermore, future studies should proceed with multidimensional verification, taking into account that the sub-factors which constitute market orientation may have an independent effect on each other.

\section{References}

Baker, W. E., \& Sinkula, J. M. (1999). The synergistic effect of market orientation and learning orientation on organizational performance. Journal of the academy of marketing science, 27(4), 411-427.

Boso, N., Story, V. M., \& Cadogan, J. W. (2013). Entrepreneurial orientation, market orientation, network ties, and performance: Study of entrepreneurial firms in a developing economy. Journal of Business Venturing, 28(6), 708-727.

Burt, R. S. (2000). The network structure of social capital. Research in organizational behavior, 22, 345-423.

Day, G. S. (1994). The capabilities of market-driven organizations. The Journal of Marketing, 37-52.

De Clercq, D., Thongpapanl, N., \& Dimov, D. (2009). When good conflict gets better and bad conflict becomes worse: The role of social capital in the conflict-innovation relationship. Journal of the Academy of Marketing Science, 37(3), 283-297.

De Clercq, D., Thongpapanl, N., \& Dimov, D. (2011). A closer look at cross- functional collaboration and product innovativeness: Contingency effects of structural and relational context. Journal of Product Innovation Management, 28(5), 680-697.

Esteban, A., Millan, A., Molina, A., \& Martin-Consuegra, D. (2002). Market orientation in service: A review and analysis. European Journal of Marketing, 36(9/10), 1003-1021.

Fornell, C., \& Larcker, D. F. (1981). Evaluating structural equation models with unobservable variables and measurement error. Journal of marketing research, 39-50.

Gulati, R., \& Singh, H. (1998). The architecture of cooperation: Managing coordination costs and appropriation concerns in strategic alliances. Administrative science quarterly, 781-814.

Hair, J. F., Ringle, C. M., \& Sarstedt, M. (2011). PLS-SEM: Indeed a silver bullet. Journal of Marketing theory and Practice, 19(2), 139-152.

Jaworski, B. J., \& Kohli, A. K. (1993). Market orientation: antecedents and consequences. The Journal of marketing, 53-70.

Kohli, A. K., \& Jaworski, B. J. (1990). Market orientation: the construct, research propositions, and managerial implications. The Journal of Marketing, 1-18.

Kohli, A. K., \& Jaworski, B. J. (1990). Market orientation: the construct, research propositions, and managerial implications. The Journal of Marketing, 1-18. 
Kohli, A. K., Jaworski, B. J., \& Kumar, A. (1993). MARKOR: a measure of market orientation. Journal of Marketing research, 467-477.

Li, Y., Zhao, Y., Tan, J., \& Liu, Y. (2008). Moderating effects of entrepreneurial orientation on market orientation- performance linkage: Evidence from Chinese small firms. Journal of small business management, 46(1), 113-133.

McEvily, B., \& Zaheer, A. (1999). Bridging ties: A source of firm heterogeneity in competitive capabilities. Strategic management journal, 20(12), 1133-1156.

Monge, P. R., Contractor, P. S., \& Contractor, N. S. (2003). Theories of communication networks. Oxford University Press, USA.

Morgan, N. A., Vorhies, D. W., \& Mason, C. H. (2009). Market orientation, marketing capabilities, and firm performance. Strategic management journal, 30(8), 909-920.

Mu, J., Thomas, E., Peng, G., \& Di Benedetto, A. (2017). Strategic orientation and new product development performance: The role of networking capability and networking ability. Industrial Marketing Management, 64, 187-201.

Narver, J. C., \& Slater, S. F. (1990). The effect of a market orientation on business profitability. The Journal of marketing, 20-35.

Singh, R. P., Hills, G. E., Lumpkin, G. T., \& Hybels, R. C. (1999). The entrepreneurial opportunity recognition process: Examining the role of self-perceived alertness and social networks. In Academy of Management Proceedings (Vol. 1999, No. 1, pp. G1-G6). Briarcliff Manor, NY 10510: Academy of Management.

Slater, S. F., \& Narver, J. C. (1994). Does competitive environment moderate the market orientation-performance relationship?. The Journal of Marketing, 46-55.

Slater, S. F., \& Narver, J. C. (1995). Market orientation and the learning organization. Journal of marketing, 59(3), 6374.

Stam, W., \& Elfring, T. (2008). Entrepreneurial orientation and new venture performance: The moderating role of intra-and extraindustry social capital. Academy of Management Journal, 51(1), 97-111.

Stam, W., Arzlanian, S., \& Elfring, T. (2014). Social capital of entrepreneurs and small firm performance: A metaanalysis of contextual and methodological moderators. Journal of Business Venturing, 29(1), 152-173.

Tenenhaus, M., Vinzi, V. E., Chatelin, Y. M., \& Lauro, C. (2005). PLS path modeling. Computational statistics \& data analysis, 48(1), 159-205.

Tsai, W., \& Ghoshal, S. (1998). Social capital and value creation: The role of intrafirm networks. Academy of management Journal, 41(4), 464-476.

Wiklund, J., \& Shepherd, D. (2003). Knowledge- based resources, entrepreneurial orientation, and the performance of small and medium- sized businesses. Strategic management journal, 24(13), 1307-1314.

Zahra, S. A. (1996). Governance, ownership, and corporate entrepreneurship: The moderating impact of industry technological opportunities. Academy of management journal, 39(6), 1713-1735.

Zahra, S. A., \& Covin, J. G. (1995). Contextual influences on the corporate entrepreneurship-performance relationship: A longitudinal analysis. Journal of business venturing, 10(1), 43-58. 